\title{
APPLICATION OF COOPERATIVE LEARNING MODEL JIGSAW IN INCREASING STUDENTS LEARNING ACHIEVEMENT OF SOCIAL SCIENCE SUBJECT
}

\author{
Elvadwi Sholissafitri ${ }^{1}$ \\ ${ }^{1}$ State Elementary School Teacher 15 of Cakranegara, Mataram, Indonesia
}

\section{Article Info}

\section{Article history:}

Received: 31-07-2021

Revised: 11-12-2021

Published: 31-01-2022

\section{Keywords:}

Cooperative Learning Jigsaw

Learning achievement

\begin{abstract}
This Classroom Action Research (CAR) aims to determine the improvement in social studies learning achievement of the fifth grade students of SDN 15 Cakranegara in the 2018-2019 school year, totaling 23 people, consisting of 14 boys and 9 girls. The research method used is: Cooperative Learning Model Jigsaw technique, with data collection techniques in the form of observation and evaluation tests, then analyzed qualitatively by comparing the success rates between cycles. The results of this study indicate an increase in the number of students who complete learning or get a score of 63 , namely 15 students in the first cycle to 18 students in the second cycle. An increase also occurred in the average value of the evaluation test given after the learning process was over, namely: 70.21 in the first cycle, to 72.39 in the second cycle. While the percentage of student learning completeness in each cycle, which is $66.67 \%$ in the first cycle, increased to $80.00 \%$ in the second cycle. In addition, the application of this method can also increase the activities of teachers and students which increase from cycle I to cycle II. This is evidenced by the percentage of teacher activity which increased from $69.10 \%$ in the first cycle with a fairly good category, to $87.85 \%$ in the second cycle with a good category. The increased student activity was marked by $68.74 \%$ in the first cycle with a fairly good category, to $82.71 \%$ in the second cycle with a good category. The Jigsaw Cooperative Learning Model has been able to improve the social studies learning achievement of fifth graders at SDN 15 Cakranegara for the 2018-2019 school year.
\end{abstract}

This is an open access article under the CC BY-SA license.

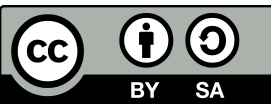

\section{Corresponding Author:}

Elvadwi Sholissafitri,

State Elementary School Teacher 15 of Cakranegara, Mataram

Jl. Ade Irma Suryani No.65, Karang Taliwang, Cakranegara, Kota Mataram, Indonesia

Email: sholissafitri7@gmail.com

\section{INTRODUCTION}

Education can be interpreted as a conscious effort carried out with the aim of improving the quality of humans, both as individual beings and social beings. Quality humans are expected to be able to understand science in certain fields, be able to reason, and think critically in solving problems to deal with problems, both for themselves and in socializing with other humans. So, in the end, they are able to face the era of globalization which is increasingly competitive and full of the development of Science and Technology. To create quality human beings, the educational process should have quality. The quality of education can be known from two 
things, namely: the quality of processes and products.

A quality education process can be seen from the implementation of effective and efficient learning by involving all components of education, such as teaching objectives, teachers and students, learning materials, teaching and learning strategies or methods, learning tools and resources and evaluation. If all these components can be managed properly, then the implementation of learning will be effective and efficient. Meanwhile, the quality of educational products can be seen from the academic achievements of students. If the academic achievement shown is above the specified standard, the educational process can be said to be of high quality. In reality, not all educational processes can be said to be of high quality. The teaching and learning process in the classroom often experiences problems. These problems can come from the students themselves, the teacher, the field of study being taught, or the infrastructure that supports learning.

Based on the results of initial observations on learning achievement in class V of SDN 15 Cakranegara in the 2018-2019 school year, the following facts were found: (1) In giving material, teachers often emphasize learning the lecture method, so it is too theoretical. In addition, during the teaching and learning process, students are less active in it. This is indicated by the student's response during the learning process. Only students with above average abilities can be actively involved in learning. (2) Many learning materials are narrative and descriptive or rote, especially in social studies subjects. (3) The average value of students' daily tests is still low, especially in social studies subjects which are lower than other subjects. This can be seen from the average daily test scores in semester 1 of the 2018-2019 school year. In the first daily test, the average value is 67 . While in the second daily test, the average value of all students is 59. This value has decreased in the third daily test, where the average value is 54 . This fact certainly does not meet the criteria Minimum completeness (KKM) set by the teacher in social studies subjects which is 63 .

From the facts above, it can be seen that the level of student achievement is still lacking, especially in social studies subjects. This shows that there are difficulties for students in studying social studies. Based on these problems, it is necessary to apply an appropriate learning model and is expected to activate students in learning. The use of the right learning model will also determine the effectiveness and efficiency of learning. One of the learning models that can be used is the Jigsaw Cooperative Learning technique. Jigsaw technique is a cooperative learning technique in which students have greater responsibility in carrying out learning. The purpose of this Jigsaw is to develop teamwork, cooperative learning skills and mastering in-depth knowledge that is impossible to obtain if they try to learn all the material alone. The Jigsaw Cooperative Learning model is very suitable for use in social studies subjects that are narrative and descriptive. Cooperative Learning jigsaw technique is learning where students learn in groups who are responsible for mastering the learning material assigned to them and then teach that part to other group members (Anitra, 2021; Handayani, 2020; Ismail, 2020; Ismayani, 2018; Mardiyanti, 2018; Marta, 2017; Suryani, 2020).

By applying the Jigsaw Cooperative Learning technique, it is possible to increase student activity, cooperation, and motivation in the implementation of learning, which is later expected to improve student learning achievement, especially in social studies. Improving learning achievement fosters quality education. Based on this thought, it is necessary and important to carry out classroom action research regarding the Application of the Jigsaw Technique Cooperative Learning Model to Improve Social Studies Learning Achievement for Class V SDN 15 Cakranegara Academic Years 2018-2019.

\section{RESEARCH METHOD}

This CAR procedure is carried out in accordance with the changes to be achieved. With a clear division of group tasks, students discuss with group members, both home groups and expert groups to be directly involved in processing information so that students can interact and work together to understand the subject matter. This research consists of 2 cycles, where each cycle contains changes in the learning process which are analyzed and become a reference for the implementation of the next cycle. The procedures or steps of the research carried out are divided into activity cycles, where each cycle consists of 4 main activities, including: (a) Planning, (b) Implementation Action, (c) Observation/observation and (d) Reflection, and the model design from Lewin which was interpreted by Kemmis (Arikunto, 2012; Fatimah, 2021; Jufri, 2010; Nurdin, 2016; Widayati, 2014).

This research is said to be successful if (1) There was an increase in teacher activity and student learning activities after being taught by applying the Jigsaw type cooperative learning model. This learning activity is said to increase if there is an increase in the average score from the previous cycle and the minimum 
criteria for student learning activities are in good category. (2) The results of the learning test showed individual learning completeness of 70. (3) The results of the learning test obtained an average grade of 75 and classical learning completeness reached $85 \%$.

\section{RESULT AND DISCUSSION}

\subsection{Data Research Description}

In this chapter, the results of research that have been carried out are presented in the form of actions or processes and learning outcomes using the Jigsaw Cooperative Learning model to improve social studies learning achievement for fifth grade students at SDN 15 Cakranegara. In addition, this chapter also presents the results of reflection on the results of the research and discussion of research results. The data is presented sequentially according to the order of implementation of each cycle.

\subsection{Results of the Cycle Implementation}

\subsubsection{Cycle I}

The learning process in the first cycle with the application of the Cooperative Learning model of the Jigsaw technique was carried out in 2 meetings, each of which had a time allocation of $3 \times 35$ minutes. The activities in cycle I consist of 5 stages, including:

1. Pre-Reflection

At this stage, the identification of students' difficulties in understanding the concept of social studies learning is carried out. This identification can be done by looking at the previous students' abilities in studying the material in social studies and the scores obtained by students before applying the Jigsaw Cooperative Learning technique. In addition, identification is also carried out by observing the methods/methods used by the teacher in teaching.

Based on the results of the initial reflection, it is known that students have difficulty in understanding the narrative and descriptive social science learning concepts. This can be seen from the average value of students' daily social studies tests in semester 1 of the 2018-2019 school year. In the first daily test, the average value is 67 . While in the second daily test, the average value of all students is 59 . This value has decreased in the third daily test, where the average value is 54. In addition, based on the recapitulation of the score In the first semester test, it is known that the average score of students is 6.08 . This fact certainly does not meet the minimum completeness criteria (KKM) set by the teacher in social studies subjects, which is 63. (Source: Recapitulation of grade V grades at SDN 15 Cakranegara, 2018-2019).

2. Action Planning

At this stage the researcher prepares a plan of action to be carried out, in the form of:

(a) Learning Implementation Plan (RPP) in which the Jigsaw technique Cooperative Learning model is applied as specified (attachment 2);

(b) Student Worksheet Instruments (LKS) in groups that will be used as a reference for the implementation of Cooperative Learning Jigsaw techniques (appendix 3);

(c) The instrument for evaluating student learning outcomes/evaluating questions on the learning activities carried out (attachment 5);

(d) The instrument for observing the teacher's activity during the learning process takes place (appendix 7);

(e) The instrument of student activity observation sheet during the learning process takes place to determine the level of success of the implementation of the actions that have been carried out (appendix 8);

(f) Facilities, learning resources, and learning media needed in learning social studies subjects the subject of the struggle of the fighters during the Dutch colonial period.

3. Action

(a) First Meeting

The implementation of the first cycle of learning with the application of Cooperative Learning Jigsaw technique in class V of SDN 15 Cakranegara was carried out on Wednesday, April 1, 2019 during the second lesson, starting at 09.30 - 11.15 WITA with the subject of the struggle of the fighters during the Dutch and Japanese colonial times. At the beginning of the meeting, the teacher greets students, checks student attendance and conditions students so that they are ready to receive lessons. Next, the 
teacher makes apperception about the learning material and informs the material being studied and the learning objectives. All students listened carefully.

Entering the core activity, the teacher demonstrates pictures of independence fighters from several regions which the students will guess. There are 8 pictures of warrior figures displayed by the teacher. Students guess one by one according to their initial ability. In this activity, there are several pictures of characters that the students cannot guess. The activity continued by explaining the forms of resistance carried out by the warrior figures. After explaining the overall form of resistance of the Indonesian people against Dutch colonialism, the students then gathered in their home groups. In the original group, students are given worksheets with the distribution of material in it. Each student in the original group received different material. Then they try to find information in various book sources based on the material obtained. Here students are emphasized to be able to find information that is in accordance with the questions or instructions from the worksheets that have been given. After that, students with the same material in each group gathered to form an expert group with the aim of trying to master the material received and discuss how to transmit the material/information to their home group.

To increase the activity and understanding of students in the expert group, students were given a game in the form of compiling pictures of several national warrior figures who fought against Dutch colonialism from various regions with pieces of pictures that had been prepared in envelopes. Then students in the expert group look for the name and origin of the character and write it down. It should be noted that one of the image pieces in each expert group belongs to the randomized image of the other group. So, one of the students can be asked by the expert group to search and find the appropriate pieces of the picture. This is a form of student interaction with other expert groups. In asking for the piece of the picture, students are expected to be able to ask for it in a kind/polite way. If there are students who ask in a bad way, then the piece of the picture cannot be given. This is a form of sanctions against the value of politeness that is not applied by students.

After the picture is assembled perfectly, students in the expert group write down the name of the character and the area of origin. In this case, each expert group assembles a picture of a fighter figure that is not discussed by them, but a fighter figure discussed by another group that was previously randomized. It is intended that students in the expert group are not only fixated on the warrior figures they study, but the warrior figures studied by other expert groups.

The activity ended by testing the understanding of students in the expert group by giving questions related to the material they mastered. Each student gets 10 questions that they have to work on together. These questions were then discussed in each expert group for evaluation. If there is an incorrect answer, it can be corrected by the student, because it will be transmitted to the original group. After that, the teacher and students conclude the learning activities and close.

(b) Second Meeting

The second meeting in cycle I was held on Saturday, April 4, 2019, exactly three days after the first meeting in cycle I. The learning process took place at 07.30-09.15 WITA. The initial activity at the second meeting began with apperception in the form of asking several questions related to the material that had been studied at the first meeting. In this activity, about $60 \%-70 \%$ of students were able to answer questions posed by the teacher.

The next activity is that all students gather in expert groups, then refresh their memories a little about the material given at the previous meeting by asking questions about the material at the previous meeting. Students then sit back down based on their original group, then begin to transmit the information they have previously mastered to other group members. In this stage of transmission, there is a discussion between members in the original group. Each student explains their material to their members, after that they discuss the questions that were worked on in the expert group at the first meeting. And so on, continued by other group members, until all students have finished transmitting the information.

The activity was continued by presenting the results of group discussions. However, the presentations were not comprehensive to each origin group, but complemented each other between the origin groups. Each home group is represented by 2 or 3 members to present the results of their discussion. If there are questions from other groups, all students in the home group have the right to answer them. The learning activity ended by working on evaluation questions as many as 20 multiple choice questions to test students' understanding of the material that had been studied. 
4. Observation and Evaluation

(a) Observation

Observations on teacher and student activities are carried out during the learning activities. In this stage, data is collected with the assistance of two observers who are tasked with observing the implementation of learning in the classroom from the beginning to the end of learning in two meetings, both teacher activities and student activities using the provided observation sheet.

By referring to the observation sheet that has been filled in by the two observers in two meetings in the first cycle, the following data are obtained:

Table 1. Results of Observation of Teacher Activities in Cycle I

\begin{tabular}{llc}
\hline No. & Indicator & Percentage \\
\hline 1 & Generating student interest and motivation in learning & $56.25 \%$ \\
2 & Apperception & $68.75 \%$ \\
3 & Submission of material to students & $68.75 \%$ \\
4 & Guiding students in learning activities & $87.50 \%$ \\
5 & Ability to create a conducive classroom atmosphere & $83.34 \%$ \\
6 & Ending Learning & $50.00 \%$ \\
\hline Average percentage in cycle I & $69.10 \%$ \\
\hline Category & Pretty good \\
\hline
\end{tabular}

From the table of observations of teacher activities above, it can be seen that the percentage of teacher activity in the first indicator, namely generating student interest and motivation in learning is $45.84 \%$ at the first meeting and $66.67 \%$ at the second meeting. Although at the second meeting the percentage increased, this figure was still lacking. This can be seen from the learning process carried out, where the efforts made by the teacher to arouse student interest and motivation have not been maximized. In addition, the percentage of teacher activities in delivering material to students is still below the expected performance indicators. This of course affects the level of students' understanding of the material being taught.

Overall, in the table above, it can also be seen that the percentage of teacher activity scores both at the first and second meetings in the research for the first cycle is $69.10 \%$ with a fairly good category. This shows that the expected teacher activities are still less than the specified performance indicators

(b) Student Activity Data

By referring to the observation sheet that has been filled in by the two observers in two meetings in the first cycle, the student activity data obtained are as follows:

Table 2. Results of Observation of Student Activities in Cycle I

\begin{tabular}{llc}
\hline No. & Indicator & Percentage \\
\hline 1 & Enthusiasm of students in participating in learning activities & $81.25 \%$ \\
2 & Student interaction with teacher & $60.42 \%$ \\
3 & Student activities with students in groups & $61.45 \%$ \\
4 & Student participation in the reflection of learning outcomes & $71.87 \%$ \\
\hline Average percentage in cycle I & $68.74 \%$ \\
\hline Category & Pretty good \\
\hline
\end{tabular}

From the table of student activity observations above, it can be seen which indicators of student activity are still lacking. Student activities that are still lacking include indicators of student-teacher interaction (with a percentage of $54.17 \%$ at the first meeting, and $66.67 \%$ at the second meeting) and student activities with students in groups (with a percentage of $58.33 \%$ at the first meeting), and $64.58 \%$ at the second meeting). The percentages on these two indicators did increase in the second meeting, but have not yet reached the desired standard. This becomes a reference in the implementation of the next cycle.

From the facts above, it can be seen that there are 3 indicators out of 4 indicators of student activity that are still lacking or below the expected performance indicators. The indicators that are still lacking are the second indicator (student interaction with the teacher), the third indicator (student activity with students in groups), and the fourth indicator, namely student participation in the reflection of learn- 
ing outcomes. The lack of interaction between students and teachers can be seen from the number of students who ask questions about material that has not been understood yet. In addition, student responses were also low to questions asked by the teacher regarding the material presented. Meanwhile, the activities of students in groups that are still less visible are.

Overall, the facts above also show that the percentage of student activity scores both at the first and second meetings in the research for the first cycle is $68.74 \%$ with a fairly good category. This shows that the expected student activities are still less than the specified performance indicators.

\section{Reflection}

Based on all the results in the table above, it can be said that the implementation of the first cycle has not reached the standard that has been set. In addition, from the data above, several problems in the implementation of the first cycle can be obtained which can later be corrected in the second cycle. These problems become deficiencies in the implementation of cycle I. These deficiencies can be detailed as follows:

(a) Teachers do not arouse students' interest and motivation in learning, especially in studying broad social studies material. This can be seen from the lack of percentage of this indicator in the observation sheet. For this reason, it is necessary to have a second cycle by preparing efforts that must be sought by learning implementers, in this case the teacher himself to increase students' interest and motivation in learning social studies.

(b) In the discussion with the two observers, it was found that there was a problem regarding the allocation of time that was still insufficient to carry out learning with the Jigsaw Cooperative Learning technique. Therefore, for the next cycle, the teacher is expected to be able to manage the available time so that learning can run according to the goals set.

(c) From the student activity data above, it can also be seen that the interaction between teachers and students is still lacking. Therefore, for the implementation of the next cycle, it is hoped that the teacher can increase his interaction with students, especially in group discussions and classical discussions.

(d) The teacher does not give awards to the best groups that present the results of their discussions. For this reason, in the next cycle, it is hoped that the teacher can give awards to groups of students who are considered good in appearance. At least by giving applause to the group that has shown the results of the discussion well.

(e) There is still a lack of activity between students and students in groups. Although learning has been inserted with games, there are still less active students. To overcome this, students can be given guidance to be able to manage the division of tasks in their groups, so that student activities in groups can be more lively.

(f) Students have not been able to conclude the learning outcomes that have been implemented. This was proven when the learning process took place, only 5 students raised their hands to express opinions regarding the learning conclusions. Therefore, in the next cycle, the teacher should guide students more to be able to submit their opinions even though they are wrong.

(g) The response of students to their friends who transmit the material is still lacking. This can be seen from the observation sheet and the value of learning achievement which is still lacking with only $66.67 \%$ of students who are considered to have completed learning. This shows that students lack mastery of the material, both the material itself and the material transmitted by their friends. Therefore, it needs improvement.

\subsubsection{Cycle II}

Basically, the second cycle is an improvement from the implementation of the first cycle. The second cycle was carried out as an effort to improve the first cycle whose results did not meet the established standards. The learning process in cycle II with the application of the Jigsaw technique Cooperative Learning model was carried out in 2 meetings, each meeting had a time allocation of $3 \times 35$ minutes. The subject that will be studied as research material is the events surrounding the Proclamation. The activities in cycle II consist of 4 stages, among others:

1. Action Planning

At this stage the researcher prepares a plan of action to be carried out, in the form of:

(a) The Learning Implementation Plan (RPP) in which the Cooperative Learning model of the Jigsaw technique is applied as has been determined

(b) Student Worksheet Instruments (LKS) in groups that will be used as a reference for the implementation 
of Cooperative Learning Jigsaw techniques

(c) The instrument for evaluating student learning outcomes/evaluating questions on the learning activities carried out

(d) The instrument for observing the teacher's activity during the learning process takes place

(e) The instrument of student activity observation sheet during the learning process takes place to determine the level of success of the implementation of the actions that have been carried out

(f) Facilities, learning resources, and learning media needed in learning social studies subjects on the subject of the struggle of the fighters during the Dutch colonial period.

2. Action

(a) First Meeting

The implementation of the first meeting of the second cycle of learning action with the application of Cooperative Learning Jigsaw techniques in class V of SDN 15 Cakranegara was held on Monday, April 6, 2019 during the second lesson, starting at 09.30-11.15 WITA, with the subject matter of events around the Proclamation. At the beginning of the meeting, the teacher greets students, checks student attendance and conditions students so that they are ready to receive lessons. Next, the teacher makes an apperception of the learning material by asking several questions that lead to the material and informs the material to be studied and the learning objectives. All students listen and pay close attention. Entering the core activity, the teacher demonstrates pictures of important figures who played a role in the preparation for Indonesian Independence, which the students will guess. There are 6 pictures of important figures who played a role in the preparation of Indonesian Independence as well as pictures of the events leading up to the proclamation that were displayed by the teacher. Students guess one by one according to their initial ability. In this activity, there are several pictures of characters that the students cannot guess. This is because the picture of the character is still unknown to students.

The activity continued by explaining the condition of Indonesia when it was colonized by Japan until the atomic bombings in Hiroshima and Nagasaki. After that, students then gather in their original group. In the original group, students are given worksheets with the distribution of material in it. Each student in the original group received different material. Then they try to find information in various book sources based on the material obtained. Similar to cycle I, here students are emphasized to be able to find information that is in accordance with the questions or instructions from the worksheets that have been given. After that, students with the same material in each group gathered to form an expert group with the aim of trying to master the material received together by complementing each other and discussing how to transmit the material/information to their home group.

The activity was continued by testing the understanding of students in the expert group by giving questions related to the material they mastered. Each student gets 10 questions that they have to work on together. To save time, students are guided to be able to work on the 10 questions by dividing the task, where each student gets the task of working on 1 item, while the other 4 questions are done together. These questions were then discussed in each expert group for evaluation. If there is an incorrect answer, it can be corrected by the student, because it will be transmitted to the original group. After that, the teacher and students concluded the learning activities and closed. Learning conclusions are obtained by drawing students' opinions on the material discussed.

(b) Second Meeting

The second meeting in cycle II was held on Wednesday, April 8 2019, exactly two days after the first meeting in cycle II. The learning process takes place at 07.30-09.30 WITA, slightly exceeding the specified time. The initial activity at the second meeting began with apperception in the form of asking several questions related to the material that had been studied at the first meeting and showing pictures of the figures who played a role in the events of the Proclamation and pictures of the events leading up to the Proclamation. Almost all students can answer the questions asked by the teacher and guess the picture shown.

The activity continued with the gathering of students based on their original group, then began to transmit the information they had previously mastered to other group members. Similar to the activities in cycle I, in this transmission stage there was a discussion between members in the original group. Each student explains their material to their members, after that they discuss the questions that were worked on in the expert group at the first meeting. And so on, continued by other group members, until all students have finished transmitting the information. To further activate students, the teacher 
gives a game to the home group. They were given LKS and envelopes containing pictures of important events leading up to the Proclamation and sentence fragments, which later on these pictures would be assembled in accordance with the sequence of events leading up to the Proclamation. Then students are asked to match the sentences that match the pictures earlier. So that all group members are directly involved.

The activity was continued by presenting the results of group discussions. However, as with the group presentations in cycle I, the presentations were only represented by 2 or 3 members of the original group. If there are questions from other groups, all students in the home group have the right to answer them. In the classical discussion process with this presentation, the teacher guides the discussion. The classical discussion that was carried out looked more lively. This is evident from every presentation delivered, many questions are asked by other groups to the presenting group. So that almost all members in the original group who got their turn in presentations had the opportunity to answer questions posed by other groups.

Before ending the lesson, students with the direction of the teacher try to conclude the material that has been studied together. In the first cycle and the first meeting in the second cycle students were less active in concluding the material, but in the second meeting of the second cycle, students were more active in scrambling to express their opinions to conclude the material. The learning activity ended by working on evaluation questions as many as 20 multiple choice questions as in the first cycle to test students' understanding of the material that had been studied. The results of the evaluation will be used as a measuring tool for the success of research in this second cycle as well as a determinant of the success of research with Cooperative Learning Jigsaw techniques in fifth grade students at SDN 15 Cakranegara.

3. Observation and Evaluation

(a) Observation

Observations on teacher and student activities in cycle II were carried out during the learning activities. The data collected was assisted by two observers in charge of observing the implementation of learning in the classroom from the beginning to the end of learning in two meetings, both teacher activities and student activities using the existing observation sheets.

By referring to the observation sheet that has been filled in by the two observers in two meetings in cycle II, the following data are obtained:

Table 3. Results of Observation of Teacher Activities in Cycle II

\begin{tabular}{llc}
\hline No. & Indicator & Percentage \\
\hline 1 & Generating student interest and motivation in learning & $89.58 \%$ \\
2 & Apperception & $81.25 \%$ \\
3 & Submission of material to students & $89.58 \%$ \\
4 & Guiding students in learning activities & $87.50 \%$ \\
5 & Ability to create a conducive classroom atmosphere & $91.67 \%$ \\
6 & Ending Learning & $87.50 \%$ \\
\hline Average percentage in cycle I & $87.85 \%$ \\
\hline Category & Good \\
\hline
\end{tabular}

From the table of teacher activity observations above, it can be seen that the percentage of teacher activity for all existing indicators has increased from cycle I. In addition, the percentage shown has exceeded the expected performance indicators. The percentage of teacher activity at the first meeting was $85.59 \%$ with a good category. Meanwhile, at the second meeting the percentage rose to $90.10 \%$ in the very good category. So, the average percentage for teacher activities in the second cycle is $87.85 \%$ with a good category. This shows that the expected teacher activities have reached and even exceeded the expected performance indicators.

In the implementation of the first cycle, the indicators of teacher activity in the form of arousing students' interest and motivation, delivering material and ending learning were still less than 75\% (expected performance indicators). Meanwhile, in the second cycle, it can be seen that the percentages for the three indicators have met and even exceeded the expected performance indicators. So, it can be said that the teacher's activity in learning increased from cycle I to cycle II. reflection on the implementation 
of cycle I.

By referring to the observation sheet that has been filled in by the two observers in two meetings in cycle II, the student activity data is obtained as follows:

Table 4. Results of Observation of Student Activities in Cycle II

\begin{tabular}{llc}
\hline No. & Indicator & Percentage \\
\hline 1 & Enthusiasm of students in participating in learning activities & $82.81 \%$ \\
2 & Student interaction with teacher & $77.08 \%$ \\
3 & Student activities with students in groups & $81.24 \%$ \\
4 & Student participation in the reflection of learning outcomes & $89.72 \%$ \\
\hline Average percentage in cycle I & $82.71 \%$ \\
\hline Category & Good \\
\hline
\end{tabular}

From the table of observation results of student activities above, it can be seen that all indicators of student activity have even exceeded the expected performance indicators. At the first meeting, the percentage of student activity was $79.75 \%$ with a good category. This percentage amount increases at pertemuan kedua, yaitu mencapai $85,67 \%$ dengan kategori baik. Sedangkan rata-rata persentase aktifitas siswa pada siklus II ini adalah $82,71 \%$ dengan kategori baik atau meningkat dari persentase pada siklus I.

The data above also shows an increase in student activity from cycle I to cycle II. In the first cycle, student activities are still below the expected performance indicators, which can be seen in the second indicator, namely the lack of interaction between students and teachers, the third indicator, namely student activities with students in groups, and the fourth indicator, namely student participation in the reflection of learning outcomes. However, the data on student activity in cycle II shown above shows that the three indicators have already reached some and some have even exceeded the expected performance indicators. This shows an increase in student activity from cycle I to cycle II.

(b) Evaluation

Evaluation was carried out on student achievement data after a student understanding test was carried out on the actions that had been carried out in cycle II. This test technique is written in the form of multiple choice as many as 20 questions. After the test, the following data were obtained:

Table 5. Evaluation results of cycle II

\begin{tabular}{lcccl}
\hline No & Score & Summary & Percentage(\%) & Completeness(\%) \\
\hline 1 & $90-100$ & 8 & 36.67 & \\
2 & $80-89$ & 5 & 23.33 & 80.00 (Complete) \\
3 & $63-79$ & 5 & 20.00 & \\
\hline 4 & $50-62$ & 5 & 20.00 & \multirow{2}{*}{20.00 (Not Complete) } \\
5 & $\leq 49$ & - & - & \\
\hline
\end{tabular}

From the table above, it can be seen that of the 23 students in class V of SDN 15 Cakranegara, there are 18 people or $80 \%$ of students can be said to be complete in learning on this subject. While 5 people or $20 \%$ of students are said to have not finished learning. This shows that learning and learning achievement is said to be increasing based on the performance indicators set, namely $75 \%$ of students are complete in learning (getting a score of 63).

It can also be seen from the data above, that students who did not complete their studies or their learning achievements did not increase were students who in the first cycle were also not complete in their studies. This is more because the ability or absorption of these students is still low. But overall, the social studies learning achievement of fifth graders at SDN 15 Cakranegara is said to have improved with the Jigsaw Cooperative Learning technique.

4. Reflection

Based on the results of observations from the entire study, starting from teacher activities, student activities and learning completeness through student learning outcomes tests, it shows that the expected performance indicators in this study have been achieved. So, it can be said that this research was successful. 


\subsection{Discussion}

This classroom action research was carried out as an effort to improve student achievement in social studies subjects in class V at SDN 15 Cakranegara through the application of the Jigsaw technique Cooperative Learning model. This research activity was carried out in two cycles, where each cycle consisted of two meetings. The first meeting was carried out by discussion groups of origin and expert groups, which could increase student activity, both with the teacher and with their peers. Meanwhile, at the second meeting, a presentation was made on the results of the group discussion, at the same time interspersed with several games. At the end of the cycle, a written test is held to determine student achievement.

During the implementation of the action in the research, the researcher acts as a teacher/teacher in charge of applying the Jigsaw Cooperative Learning model in learning activities in the classroom. The researcher was assisted by two teachers at the research location who served as observers, namely Ms. Hermawati Diah, S.Pd (VI grade homeroom) and Ms. Epi Supiana, S.Pd (5th grade homeroom teacher). The two observers observed the behavior of teachers and students during learning activities using the available observation guidelines.

From the result, it is known that the percentage of student learning activities from cycle I to cycle II is increasing. In the first cycle, the percentage of student activity was only $68.74 \%$ with a fairly good category. The insufficient percentage of student activity is caused by several obstacles, including: a). There is still a lack of activity between students and students in groups. Although learning has been inserted with games, there are still fewer active students. To overcome this, students can be given guidance to be able to manage the division of tasks in their groups, so that student activities in groups can be livelier. In addition, groups that look cooperative and compact can be given awards, for example in the form of applause. b). Students have not been able to conclude the learning outcomes that have been implemented. This was proven when the learning process took place, only 5 students raised their hands to express opinions regarding the learning conclusions. Therefore, to overcome this, the teacher can give additional points to students who dare to express their opinions in an effort to find material conclusions in learning. c). Student responses to their friends who transmit the material are still lacking. This can be seen from the observation sheet and the value of learning achievement which is still lacking with only $66.67 \%$ of students considered to have completed learning (in the first cycle). This shows that students lack mastery of the material, both the material itself and the material transmitted by their friends. Therefore, it is necessary to improve by considering all existing deficiencies, so that the number of learning mastery can reach the expected percentage.

Although there are several obstacles, basically there is an increase in student activity for each cycle. This is evident in the second cycle where the percentage of student activity increased by $13.97 \%$ to $82.71 \%$ in the good category. The increase in student activity was due to improvements in planning and implementation of learning in cycle II based on the results of reflection in cycle I, so the researchers tried their best to improve the shortcomings in cycle I. Overall, the learning that had been carried out in this study was in accordance with the characteristics of the students. characteristics of Cooperative Learning Jigsaw technique proposed by Anita Lie in her book entitled: Cooperative Learning (2002: 69), which states that students work with fellow students in an atmosphere of mutual cooperation and have many opportunities to process information and improve communication skills.

The research efforts or actions carried out above are a form of a series of implementations of the Jigsaw Cooperative Learning technique which is a form of variation in the method or learning model that aims to improve learning activities and student learning outcomes. This is in accordance with the opinion expressed by Slameto (2003: 17) in his book entitled Learning and the Factors Affecting It, that with a variety of methods, can improve student learning activities.

Cooperative Learning Model Jigsaw technique can improve student achievement. This conclusion was obtained based on the percentage of mastery learning from the results of the student learning evaluation tests carried out at the end of each cycle which experienced an increase. This is evident from the data presented in the table above. Student achievement in the first cycle was $66.67 \%$ with an average value of 69.83 . This percentage and average value increased in the second cycle, which was up to $80.00 \%$ with an average value of $78.83 \%$. This fact certainly shows that this research is successful, with reference to the expected performance indicators.

The improvement as described above can be influenced by the efforts to correct the actions taken by the teacher based on observations of the obstacles/lacknesses obtained. The corrective actions include: a). the teacher attracts students' interest and motivation to learn with demonstrations of pictures and games that are 
inserted in learning, b). the teacher provides opportunities for students to ask questions about material that has not been mastered and provides opportunities for students to express their opinions in learning, especially in the implementation of discussions, both group discussions and classical discussions, by adding points for students who dare to express opinions, c). the teacher tries to learn from mistakes or deficiencies in the first cycle which causes the percentage of student activity and achievement to be below the expected performance indicators.

Overall, the actions taken from cycle I to cycle II showed improvement and improvement in student achievement. This can be seen from the increase in results and the learning process. The results of this study are in accordance with the opinion of Anita Lie in her book Cooperative Learning (2002: 69) which says that: Peer teaching is effective in boosting student achievement than teacher teaching. Cooperative Learning Jigsaw technique is a form of peer teaching. Thus, it can be said that the application of the Jigsaw technique Cooperative Learning model can improve social studies learning achievement for fifth grade students at SDN 15 Cakranegara in the 2018-2019 school year.

\section{CONCLUSION}

Based on the whole series of results of classroom action research conducted by the researcher for 2 cycles, as well as the analysis and discussion that has been carried out, there are 3 things that the researcher can conclude, namely (1) The application of the Jigsaw technique Cooperative Learning model was able to improve the learning achievement of fifth grade students at SDN 15 Cakranegara in the 2018-2019 academic year in social studies subjects. This can be concluded based on the increase in the number of students who complete learning from cycle I to cycle II, which is getting a score of 63 (KKM specified). As many as 15 students have completed learning in the first cycle, and have increased the number in the second cycle to 18 students have completed learning. From the number of students who completed the study, it is also known that the percentage of student learning completeness increased from the first cycle with $66.67 \%$, to the second cycle with $80.00 \%$. This increase in achievement can also be seen from the average score of students which increased to each cycle, namely the value of 69.83 in the first cycle and increased in the second cycle to 78.83. (2) The application of the Cooperative Learning model of the Jigsaw technique is proven to be able to increase the activities of Class V students at SDN 15 Cakranegara in the 2018-2019 academic year towards social studies subjects. This is indicated by the percentage in each observed aspect which increases from cycle I to cycle II. Based on observations, the percentage of student activity in the first cycle was $68.74 \%$. This percentage increased in the second cycle to $82.71 \%$. This fact shows an increase of $13.97 \%$. (3) Based on the results of observations of teacher activities in the learning process, it was found that there was an increase in teacher activity in carrying out learning by applying the Jigsaw technique Cooperative Learning model. This is evidenced by the achievement of a fairly good category in the first cycle (with a percentage of $69.10 \%$ ) to a good category in the second cycle (with a percentage of $87.85 \%$ ).

\section{REFERENCES}

Anitra, R. (2021). Pembelajaran Kooperatif Tipe Jigsaw dalam Pembelajaran Matematika di Sekolah Dasar. JPDI (Jurnal Pendidikan Dasar Indonesia), 6(1), 8. doi:10.26737/jpdi.v6i1.2311

Arikunto, S. (2012). Prosedur Penelitian : Suatu Pendekatan Praktik (Edisi Revisi).

Fatimah, F. N. (2021). Peningkatan Hasil Belajar Siswa pada Materi Bagian Tumbuhan melalui Metode STAD di Kelas IV SDN 1 Joho Kecamatan Pace Kabupaten Nganjuk. PTK: Jurnal Tindakan Kelas, 2(1), 62-67. doi: $10.53624 /$ ptk.v2i1.44

Handayani, H. (2020). PENGARUH IMPLEMENTASI PEMBELAJARAN KOOPERATIF TIPE JIGSAW TERHADAP KEMAMPUAN BERPIKIR KRITIS MATEMATIS SISWA SEKOLAH DASAR. Pendas : Jurnal Ilmiah Pendidikan Dasar, (Vol 5 No 1 June 2020). doi:10.23969/jp.v5i1.1944

Ismail, I. (2020). The Application of Jigsaw Cooperative Learning Model towards the Improvement of Students' Critical Thinking Ability in Public Senior High School 15 Banda Aceh, Indonesia. Budapest International Research and Critics in Linguistics and Education (BirLE) Journal, 3(2), 1113-1122. doi:10.33258/birle.v3i2.1044

Ismayani, L. (2018). Upaya Meningkatkan Hasil Belajar Matematika Bangun Ruang dengan Menggunakan Model Pembelajaran Kooperatif Tipe Jigsaw. Journal of Elementary School (JOES), 1(1), 22-34. doi:10. 31539/joes.v1i1.222 
Jufri, A. W. (2010). PENELITIAN TINDAKAN KELAS: ANTARA TEORI DAN PRAKTEK. JURNAL PIJAR MIPA, 5(2). doi:10.29303/jpm.v5i2.166

Mardiyanti, I. (2018). PENGARUH MODEL COOPERATIF LEARNING TIPE JIGSAW TERHADAP HASIL BELAJAR MATA KULIAH PENANGANAN KEGAWATDARURATAN PADA MAHASISWA SEMESTER V. Journal of Health Sciences, 9(1). doi:10.33086/jhs.v9i1.186

Marta, R. (2017). Peningkatan Hasil Belajar Luas Bangun Datar melalui Model Kooperatif Tipe Jigsaw Bagi Siswa Kelas V SD Negeri 003 Bangkinang Kota. Jurnal Basicedu, 1(1), 45-54. doi:10.31004/basicedu. v1i1.152

Nurdin, S. (2016). Guru Profesional dan Penelitian Tindakan Kelas. Jurnal Educative : Journal of Educational Studies, 1(1). doi:10.30983/educative.v1i1.118

Suryani, S. (2020). PENGGUNAAN METODE KOOPERATIF TIPE JIGSAW UNTUK MENINGKATKAN PRESTASI BELAJAR MATEMATIKA SISWA KELAS IV SD NEGERI PAJAMBON. Pedagogi: Jurnal Penelitian Pendidikan, 6(1). doi:10.25134/pedagogi.v6i1.1893

Widayati, A. (2014). PENELITIAN TINDAKAN KELAS. Jurnal Pendidikan Akuntansi Indonesia, 6(1). doi:10. 21831/jpai.v6i1.1793 